\title{
Does the Data Tell the True Story? A Modelling Study of Early COVID-19 Pandemic Suppression and Mitigation Strategies in Ghana
}

\author{
Nana Kena Frempong ${ }^{1}$, Theophilus Acheampong*2, Ofosuhene O. Apenteng ${ }^{3}$, \\ Emmanuel Nakua 4 , John H. Amuasi* 5,6,7
}

\begin{abstract}
This paper uses publicly available data and various statistical models to estimate the basic reproduction number $\left(R_{0}\right)$ and other disease parameters for the early COVID-19 pandemic outbreak in Ghana. We also test the effectiveness of government imposition of public health measures to reduce the risk of transmission and impact of the pandemic, especially in the early phase. $R_{0}$ is estimated from the statistical model as 3.21 using a 0.147 estimated growth rate [95\% C.I.: 0.137-0.157] and a 15-day time to recovery after COVID-19 infection. This estimate of the initial $R_{0}$ is consistent with others reported in the literature from other parts of Africa, China and Europe. Our results also indicate that COVID-19 transmission reduced consistently in Ghana after the imposition of public health interventions - such as border restrictions, intra-city movement, quarantine and isolation - during the first phase of the pandemic from March to May 2020. However, the time-dependent reproduction number $\left(R_{t}\right)$ beyond mid-May 2020 does not represent the true situation given there was not a consistent testing regime in place. This is also confirmed by our Jack-knife bootstrap estimates which show that the positivity rate overestimates the true incidence rate from mid-May 2020. Given concerns about virus mutations, delays in vaccination and a possible new wave of the pandemic, there is a need for systematic testing of a representative sample of the population to monitor the reproduction number. There is also an urgent need to increase the availability of testing for the general population to enable early detection, isolation and treatment of infected individuals to reduce progression to severe disease and mortality.
\end{abstract}

Keywords: COVID-19; public health; mathematical modelling; mitigation; suppression; Ghana.

\section{Introduction}

The Coronavirus disease (COVID-19), a novel infectious disease caused by the Severe Acute Respiratory Syndrome coronavirus 2 (SARS-CoV-2) was declared a global pandemic by the World Health Organization (WHO) on March 11, 2020 (Cucinotta and Vanelli, 2020; WHO, 2020a). The first reported case was in December 2019 in Wuhan, the capital of China's Hubei province, from where it quickly spread globally, reaching Sub-Saharan

\footnotetext{
${ }^{1}$ Department of Statistics and Actuarial Science, College of Science, Kwame Nkrumah University of Science and Technology (KNUST), Kumasi, Ghana.

2 Department of Economics, University of Aberdeen, United Kingdom. *Corresponding author: Email: theophilus.acheampong@abdn.ac.uk

${ }^{3}$ Research Group for Genomic Epidemiology, National Food Institute, Technical University of Denmark.

${ }^{4}$ Department of Epidemiology and Biostatistics, School of Public Health, Kwame Nkrumah University of

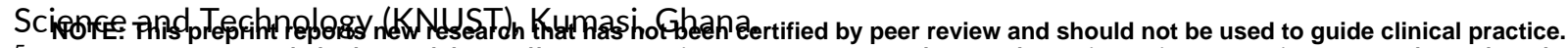

${ }^{5}$ Department of Global Health, College of Science, Kwame Nkrumah University of Science and Technology

(KNUST), Kumasi, Ghana. *Corresponding author: Email: amuasi@kccr.de

${ }^{6}$ Kumasi Center for Collaborative Research in Tropical Medicine (KCCR), Kumasi, Ghana.

${ }^{7}$ Bernhard Nocht Institute of Tropical Medicine (BNITM), Hamburg, Germany.
} 
medRxiv preprint doi: https://doi.org/10.1101/2021.05.02.21256473; this version posted May 5, 2021. The copyright holder for this preprint (which was not certified by peer review) is the author/funder, who has granted medRxiv a license to display the preprint in perpetuity. It is made available under a CC-BY-NC-ND 4.0 International license .

Africa (SSA) including Ghana (Leung et al, 2020; Cowling et al., 2020). The Africa Centre for Disease Control (AfCDC) on April 7, 2021 indicated that the continent had recorded 3.03 million cases of the virus with 2.75 million recoveries and 78,005 deaths. This represented $2.28 \%$ of all global cases (133.07 million), $2.57 \%$ of global recoveries (107.27 million), and 2.7\% of total global deaths (2.89 million) as of April 07, 2021.

Ghana reported its first case of COVID-19 on March 12, 2020. Since then, the Government of Ghana had reported 91,009 total confirmed cases with 88,810 recoveries and 752 deaths as of April 07, 2021 (Ghana Health Service, 2021; Africa CDC, 2021). In response to the outbreak, the Ghanaian government, like other sovereign nation states, imposed public health measures such as restrictions on movement, including lockdowns to contain the spread of the virus. The country closed land, air and sea borders in midMarch 2021. In addition, all educational institutions, including universities, high schools, and primary schools (both public and private) were closed. The authorities also imposed bans on public gatherings. The government subsequently on April 20, 2020, lifted a threeweek lockdown on the movement of persons within some parts of the Greater Accra, Tema, Kasoa and Greater Kumasi metropolis.

Preliminary evidence of the impact of these restrictions on the mobility patterns of populations for the period between February 17 and May 03, 2021 using anonymised and aggregated data from Ghana's Mobile Network Operators (MNOs), indicated that person movements decreased up to $60 \%$ relative to the baseline value (Ghana Statistical Service, 2020). For example, in the Greater Accra Region, where about $70 \%$ of the total cases were located at the time, person movements decreased by $20-30 \%$ during the period when initial restrictions were put in place as compared to the baseline value (Ghana Statistical Service, 2020). This further decreased by 50-60\% during the 3-week lockdown period, relative to the baseline level. A similar trend was observed for the Kumasi Metropolis which had $15 \%$ of the total cases at that time (Ghana Statistical Service, 2020).

There is a natural expectation that the lockdown and other control measures would have had some positive effect in restricting movement and physical interaction and thereby possibly slowing the spread of the virus. However, there is a need to fully explore using data, what the direction of impact and magnitude of these interventions truly was, especially in the early stages of the COVID-19 pandemic in Ghana. The emphasis on the early period of the pandemic covering March to July 2020 is particularly important because within this period, Ghana was among the few countries in Africa actively testing suspected cases and their contacts via a Tracing, Testing, and Treatment (' $3 T$ ') programme and publishing the positivity rate, (Sibiri et al., 2020; Zhang et al, 2020). For example, as at April 25, 2020, Ghana had the highest COVID-19 test per capita in SSA with a rolling 7-day average of 0.18 daily new COVID-19 tests per 1,000 people compared to South Africa's 0.13 and Senegal's 0.03 (OurWorldinData, 2021). Some of the response strategies, such as tracing and testing of contacts, were subsequently scaled back, largely due to financing constraints and the continued spread. Nevertheless, data from this early period (March to July 2020) is relatively more accurate and reliable as reflecting the epidemiology of the disease in Ghana than that collected much later, because in this early period, testing was centralized and compliance with timely reporting was high.

To formulate a valid and reliable estimate of transmissibility and spread of the COVID-19 outbreak in Ghana, we have utilised statistical modelling, which facilitates understanding of the mathematical determination of how the disease spreads. In epidemiological studies, several mathematical and statistical models have been proposed to understand the transmission dynamics of infectious diseases (Kramer et al., 2010; Diekman \& Heesterbeek; 2000, Brauer \& Castillo-Chavez, 2012; Gilbert et al., 2020; Diop et al., 2020). 
medRxiv preprint doi: https://doi.org/10.1101/2021.05.02.21256473; this version posted May 5, 2021. The copyright holder for this preprint (which was not certified by peer review) is the author/funder, who has granted medRxiv a license to display the preprint in perpetuity. It is made available under a CC-BY-NC-ND 4.0 International license .

Modelling an infectious disease such as COVID-19 in an African country with reliable data is critical to understanding the transmission dynamics so this knowledge can be applied to planning and decision-making at various levels.

To assess the intensity of an outbreak, transmissibility can be quantified by the basic reproduction number $\left(R_{0}\right)$, that is, the average number of secondary infections generated by a single primary infective in a completely susceptible population (Diekmann et al., 1990). The importance of being able to estimate the basic reproduction number ( $R_{0}$ ) becomes more apparent when an emerging infectious disease strikes a population and there is need for a tailored intervention. Monitoring the basic reproduction number provides insight into how the spread of COVID-19 is impacted by various events/interventions and is critical for decision-making in introducing or modifying (including lifting) social-distancing measures and their health and socio-economic implications (Ma et al., 2014). $\mathrm{R}_{0}$ is, therefore, the fulcrum of any predictive modelling regarding Ghana's COVID-19 epidemic curve, including any effort to estimate the impact of expected events which modify human movement and contact and most importantly, any mitigation strategies. The $R_{0}$ is therefore one of governments' key metrics for determining how well otherwise disruptive disease-spread mitigation strategies like lockdowns (of various forms) and other policies worked and might work in the future. We can also use the monitoring of the Ro to determine if these polices are worth the socioeconomic costs they impose, especially in a largely informal economy such as Ghana's (Danquah \& Schotte, 2020). $R_{0}$ is a dynamic value that can vary geographically and temporally (Ridenhour et al., 2018; Ng \& Wen, 2019.). It can be different from one day to another and from one place to another for the same disease, and its increase or decrease is determined by local conditions and human behaviour (Delamater et al., 2019; Dharmaratne et al., 2020).

Given the foregoing, the aim of this paper is to estimate the basic reproduction number $\left(R_{0}\right)$ and other disease parameters for the early evolution of the COVID-19 pandemic in Ghana. We also use our estimations to explain the epidemiology of the disease in Ghana and explore the effectiveness of the government's imposition of public health measures to suppress and mitigate the further spread of the pandemic in the country from March to July 2020. We develop a statistical model for the initial COVID-19 outbreak using various parametric growth models for the daily new cases in Ghana based on publicly available data. Additionally, we estimate the evolution of the reproduction number before a local maximum incidence of the COVID-19 pandemic in the country. Two methods are used for the estimation of the evolving $R_{0}$, namely Sequential Bayesian (SB) and Time-Dependent (TD). The Jack-knife estimation technique is also applied to the data to examine any inconsistencies in testing rates within the period under review.

\section{Methods}

\subsection{Data sources}

Data for the COVID-19 pandemic in Ghana was obtained from the Ghana Health Service, which is an agency operating under the Ministry of Health, Government of Ghana. The first 135 days after first case was reported (March 12, 2020 to July 24, 2020) was used for the analysis as the first phase of the epidemic in Ghana. Figure 1 shows COVID-19 indicators for Ghana from March to December 2020. 
medRxiv preprint doi: https://doi.org/10.1101/2021.05.02.21256473; this version posted May 5, 2021. The copyright holder for this preprint (which was not certified by peer review) is the author/funder, who has granted medRxiv a license to display the preprint in perpetuity.

Figure 1: Ghana COVID-19 daily cases (Mar-Dec 2020)

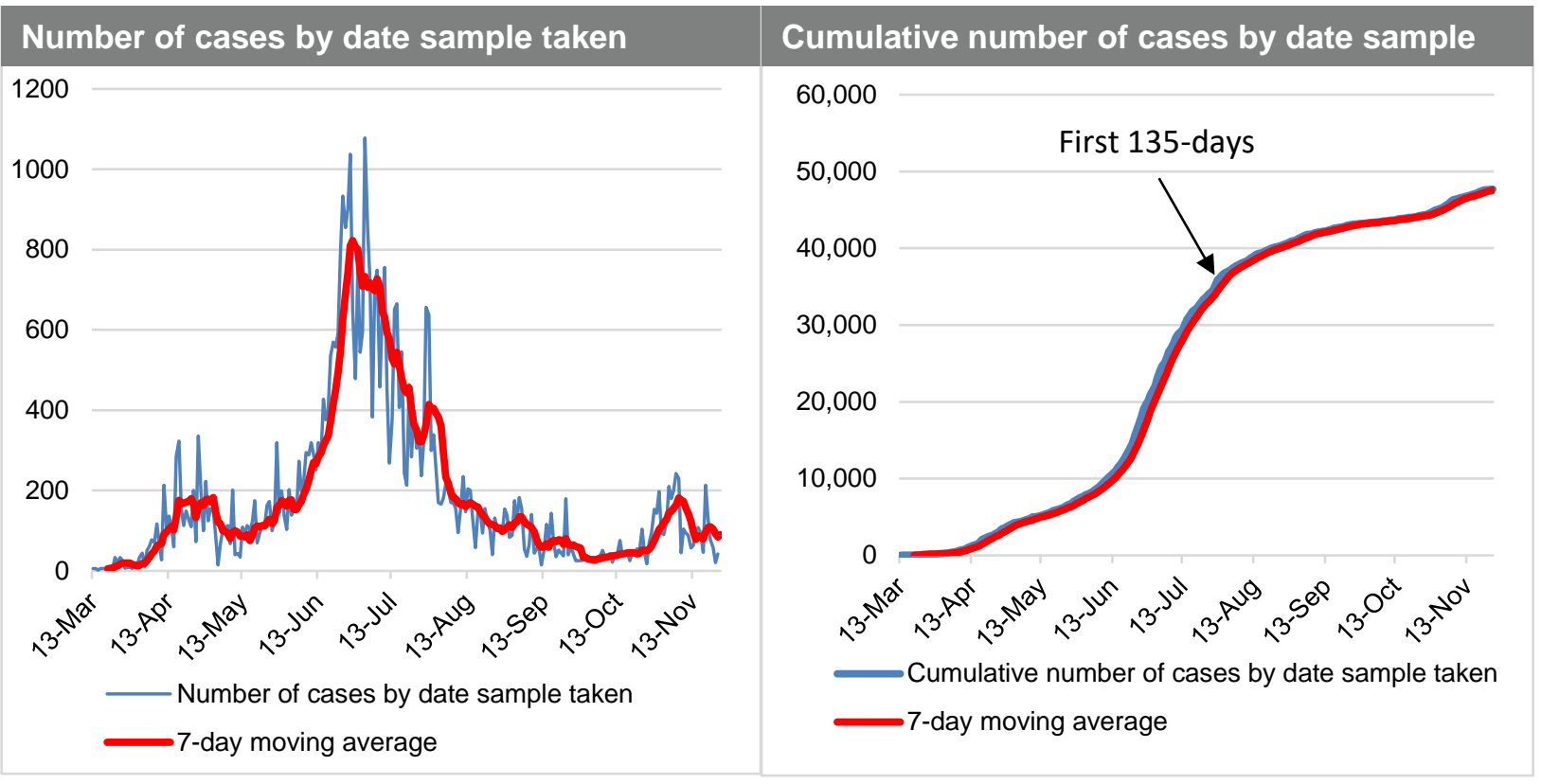

Data source: Ghana Health Service (2020)

\subsection{Statistical model for the initial COVID-19 outbreak in Ghana}

We focus on the initial stage of the epidemic using daily incidence data from the date of first reported case in the country. The weekly reported cases used was to attenuate any potential bias introduced by reporting delays. We let $Y(t)$ be the number of COVID-19 cases at time $t$. We assume that

$$
Y(t) \sim \operatorname{Poisson}(\lambda(t))
$$

where $\lambda(t)$ is the mean number of cases per unit time.

We assume that in the initial stages of the epidemic, the daily incidence cases follow some growth models. The following are the models considered to estimate the growth rate of the initial stage of the epidemic.

$$
\lambda(t)= \begin{cases}g_{0} e^{\theta t} & \text { Exponential linear model } \\ g_{0} t^{\theta} & \text { Weibull model } \\ g_{0} \frac{\alpha e^{\theta t}}{1+\alpha e^{\theta t}} & \text { Logistic growth } \\ g_{0}\left(1-e^{-\alpha e^{\theta t}}\right) & \text { Gompertz growth }\end{cases}
$$

We note that at $t>0$, the initial number of cases $g_{0}$ is a constant and used as a parameter in the model. The parameter represents the growth rate of the epidemic. An estimate of the growth rate would help to estimate the basic reproduction number for proposed mathematical model of COVID-19 (Ma, 2020). 
medRxiv preprint doi: https://doi.org/10.1101/2021.05.02.21256473; this version posted May 5, 2021. The copyright holder for this preprint (which was not certified by peer review) is the author/funder, who has granted medRxiv a license to display the preprint in perpetuity. It is made available under a CC-BY-NC-ND 4.0 International license .

\subsubsection{Estimating initial $R_{0}$ under a Generalised Linear Model (GLM) framework}

The number of COVID-19 cases at time $t$ modelled falls under the GLM framework (McCullagh and Nelder, 1989) with Poisson distribution for the response and a log link function. The exponential linear and Weibull models in Equation (2) would be formulated under the GLM while the log-logistic and Gompertz growth models are formulated under non-linear models. Using the log link, we transform the mean function of both exponential and Weibull models to a linear structure. We assume the number of cases $y\left(t_{i}\right)$ at time $t_{i}$ is independently Poisson distributed with mean $\lambda_{i}=g_{0} e^{\theta t_{i}}$.

The log-likelihood function is given as:

$$
\ell\left(g_{0}, \theta\right)=\sum_{i=1}^{n} \ln \frac{e^{-\lambda_{i}} \lambda_{i}^{y_{i}}}{y_{i} !}=\sum_{i=1}^{n}-\lambda_{i}+y_{i} \ln \lambda_{i}-\ln y_{i} !
$$

Maximizing the log-likelihood ignoring terms independent on the parameters and substituting $\lambda_{i}$ in (3).

$$
\begin{aligned}
\left(\hat{g}_{0}, \hat{\theta}\right)=\underset{\left(\hat{g}_{0}, \widehat{\theta}\right)}{\operatorname{argmax}} \sum_{i=1}^{n}-\lambda_{i}+y_{i} \ln \lambda_{i} \\
\quad=\underset{\left(\hat{g}_{0}, \widehat{\theta}\right)}{\operatorname{argmax}} \sum_{i=1}^{n}-g_{0} e^{\theta t_{i}}+y_{i} \ln g_{0}+\theta y_{i} t_{i}
\end{aligned}
$$

Similarly, for $\lambda_{i}=g_{0} t_{i}^{\theta}$ the log-likelihood is given as

$$
\begin{aligned}
\left(\hat{g}_{0}, \hat{\theta}\right)=\underset{\left(\hat{g}_{0}, \widehat{\theta}\right)}{\operatorname{argmax}} \sum_{i=1}^{n}-\lambda_{i}+y_{i} \ln \lambda_{i} \\
\quad=\underset{\left(\hat{g}_{0}, \widehat{\theta}\right)}{\operatorname{argmax}} \sum_{i=1}^{n}-g_{0} t_{i}^{\theta}+y_{i} \ln g_{0}+\theta y_{i} \ln t_{i}
\end{aligned}
$$

For $\lambda_{i}=g_{0}\left(1-e^{-\alpha e^{\theta t}}\right)$, the log-likelihood is given as

$$
\begin{aligned}
\left(\hat{g}_{0}, \hat{\alpha}, \hat{\theta}\right)=\underset{\left(\hat{g}_{0}, \hat{\alpha}, \hat{\theta}\right)}{\operatorname{argmax}} \sum_{i=1}^{n}-\lambda_{i}+y_{i} \ln \lambda_{i} \\
\quad=\underset{\left(\hat{g}_{0}, \widehat{\alpha}, \widehat{\theta}\right)}{\operatorname{argmax}} \sum_{i=1}^{n}-g_{0}\left(1-e^{-\alpha e^{\theta t_{i}}}\right)+y_{i} \ln g_{0} \\
\quad+y_{i} \ln \left(1-e^{-\alpha e^{\theta t_{i}}}\right)
\end{aligned}
$$

For $\lambda_{i}=g_{0} \frac{\alpha e^{\theta t_{i}}}{1+\alpha e^{\theta t_{i}}}$, the log-likelihood is given as

$$
\begin{aligned}
\left(\hat{g}_{0}, \hat{\alpha}, \hat{\theta}\right)=\underset{\left(\hat{g}_{0}, \hat{\alpha}, \hat{\theta}\right)}{\operatorname{argmax}} \sum_{i=1}^{n}-\lambda_{i}+y_{i} \ln \lambda_{i} \\
\quad=\underset{\left(\hat{g}_{0}, \hat{\alpha}, \widehat{\theta}\right)}{\operatorname{argmax}} \sum_{i=1}^{n}-g_{0} \frac{\alpha e^{\theta t_{i}}}{1+\alpha e^{\theta t_{i}}}+y_{i} \ln g_{0}+y_{i} \ln \lambda_{i}
\end{aligned}
$$


medRxiv preprint doi: https://doi.org/10.1101/2021.05.02.21256473; this version posted May 5, 2021. The copyright holder for this preprint (which was not certified by peer review) is the author/funder, who has granted medRxiv a license to display the preprint in perpetuity. It is made available under a CC-BY-NC-ND 4.0 International license .

This maximisation problem is solved numerically using the Newton-Raphson's algorithm.

The basic reproduction number $R_{0}$ is closely related to the initial growth rate $\theta$ under the assumption of exponentially distributed latent and infectious periods using the formula (Feng, 2007):

$$
R_{0}=\frac{\beta}{\gamma}, \theta=\beta-\gamma ; \text { where } \theta=\left(R_{0}-1\right) \gamma
$$

where $\beta, \gamma$ are the transmission and recovery rates respectively.

\subsubsection{Estimating $R_{0}$ over time before a local maximum incidence of COVID-19}

Two methods were considered for the estimation of $R_{0}$, namely sequential Bayesian (SB) and Time- Dependent (TD). These two methods rely on the generation time, which is the time lag between infection in a primary case and transmission to a secondary case. The generation time distribution is obtained from the time lag between all infective/infector pairs, as it cannot be observed directly from the data. So, we often substitute with the serial interval distribution that measures time between symptom onset. The implementation was done in the R software using the $R_{0}$ package implemented by Obadia et al. (2012). These methods rely on the assumption that the number of secondary cases caused by an index case is Poisson distributed. Given observation of $\left(N_{0}, N_{1}, \ldots, N_{T}\right)$ incident cases over consecutive time units, and a generation time distribution $\mathrm{w}, R_{0}$ is estimated by these two methods:

\section{Sequential Bayesian method (SB)}

This method relies on an approximation to the SIR model, whereby incidence at time $t+$ $1, N(t+1)$ is approximately Poisson distributed with mean

$$
\mu_{t}=N(t) e^{(\gamma(R-1))}
$$

Bayesian framework starts with a non-informative prior on the distribution of the reproduction number $R_{0}$.

The distribution is updated as new data is observed, using

$$
P\left(R \mid N_{0}, N_{1} \ldots, N_{t+1}\right)=\frac{P\left(N_{t+1} \mid R, N_{0}, \ldots N\right) P\left(R \mid N_{0}, \ldots, N_{t}\right)}{P\left(N_{0}, \ldots, N_{t+1}\right)}
$$

\section{Estimation of time-dependent reproduction numbers (TD)}

The time-dependant method proposed by Wallinga \& Teunis (2004), computes reproduction numbers by averaging over all transmission networks compatible with observations. The probability $p_{i j}$ that case $i$ with onset at time $t_{i}$ was infected by case $j$ with onset at time $t_{j}$ is calculated as

$$
p_{i j}=\frac{N_{i} w\left(t_{i}-t_{j}\right)}{\sum_{i \neq k} N_{i} w\left(t_{i}-t_{k}\right)}
$$


medRxiv preprint doi: https://doi.org/10.1101/2021.05.02.21256473; this version posted May 5, 2021. The copyright holder for this preprint (which was not certified by peer review) is the author/funder, who has granted medRxiv a license to display the preprint in perpetuity. It is made available under a CC-BY-NC-ND 4.0 International license .

The effective number for case $j$ is therefore $R_{j}=\sum_{j} p_{i j}$ and averaged as $R_{t}=$ $\frac{1}{N_{t}} \sum_{\left\{t_{j}=t\right\}} R_{j}$ over all cases with same date of onset.

\subsubsection{Estimating the impact of easing restrictions on infection rates}

Fokianos and Fried (2010, 2012) proposed intervention time series, and models interventions affecting the location by including a deterministic covariate and a decay rate. Following Fokianos and Fried $(2010,2012)$, we let $Y_{t}$ be the number of COVID-19 cases at time $t$. We assume that $Y_{t} \sim \operatorname{Neg} \operatorname{Bin}\left(\lambda_{t}, \phi\right)$, where $\lambda(t)$ is the mean number of cases per unit time and $\phi$ the dispersion parameter. In general. the linear predictor of a model with $s$ types of interventions according to parameters $\delta_{1}, \ldots, \delta_{s}$ occurring at time points $\tau_{1}, \ldots, \tau_{s}$ where $w_{m}, m=1, \ldots, s$ are intervention sizes is given as follows:

$$
\begin{aligned}
g\left(\lambda_{t}\right)=\beta_{0}+ & \sum_{k=1}^{p} \beta_{k} \tilde{g}\left(Y_{t_{-i_{k}}}\right)+\sum_{l=1}^{q} \alpha_{l} \tilde{g}\left(\lambda_{t_{-i_{l}}}\right)+\eta^{T} X_{t} \\
& +\sum_{m=1}^{s} w_{m} \delta_{m}^{t-\tau_{m}} I\left(t \geq \tau_{m}\right)
\end{aligned}
$$

The maximum likelihood estimation (MLE) is used to obtain the parameter estimates.

By identifying interventions and estimating their effect size, we allow for the identification of structural changes which can be assessed using valid statistical inferences. That is, did the said intervention have an effect on a time series during the respective period(s) in question. This is a test under the null hypothesis $\left(\mathrm{H}_{0}\right)$ of no intervention, against the alternative hypothesis $\left(\mathrm{H}_{1}\right)$ of some intervention at a known time $\tau$. If the policy interventions actually worked, then we should see a statistically significant sign on the coefficient estimates (betas). These betas are then exponentiated to get the multiplicative rate: anything above 1 indicates increase in infection rates, and those below 1 indicate a decrease in infection rates. We assume the following: no seasonality variations (daily time series data), a level shift effect (between days 5-10, rate of change of infection could be negative or positive but need to test statistical significance) for each intervention, and in some cases, the external effects of the interventions are accounted for.

\section{Results and discussion}

\subsection{Estimating the true incidence rate by correcting for inconsistencies in testing rates}

The Jack-knife method of estimating the incidence rate of COVID-19 infection has been applied to the data to correct for any inconsistencies in testing rates within the period under review (Overgaard et al., 2017; Rao et al., 2017). Ideally, to calculate the population (true) incidence rate, one needs to have consistent sampling rate (preferably per day) from a representative sample of the population, in which case the positivity rate would be expected to mirror the incidence rate. From Figure 2, the Jack-knife estimation is consistent with the actual COVID-19 case numbers observed in Ghana until May 7, 2020, from where the number of positives recorded is considerably higher than the Jack-knife estimates. This departure is consistent with the increased number of tests conducted on contact traced individual and concentrated within hotspots around that period, and neither general nor representative population level sampling. Thus, with increased testing 
medRxiv preprint doi: https://doi.org/10.1101/2021.05.02.21256473; this version posted May 5, 2021. The copyright holder for this preprint (which was not certified by peer review) is the author/funder, who has granted medRxiv a license to display the preprint in perpetuity.

It is made available under a CC-BY-NC-ND 4.0 International license.

targeted at hotspots and contacts of persons who tested positive, one would expect a higher number of positive cases. What this indicates is that there is a critical need to have consistency in testing rates, and sampling representative of the population, in order to generate a true incidence rate and furthermore, reproduction number. The forementioned estimates would form the basis of monitoring the impact of control interventions, which would inform critical policy decisions. In this regard, an exclusive focus on the actual number of positives after May 7 as the basis for measuring the state of affairs with regard to COVID-19 spread could be erroneous and lead to a false alarm.

Figure 2: Jackknife estimates versus actual number of positive cases

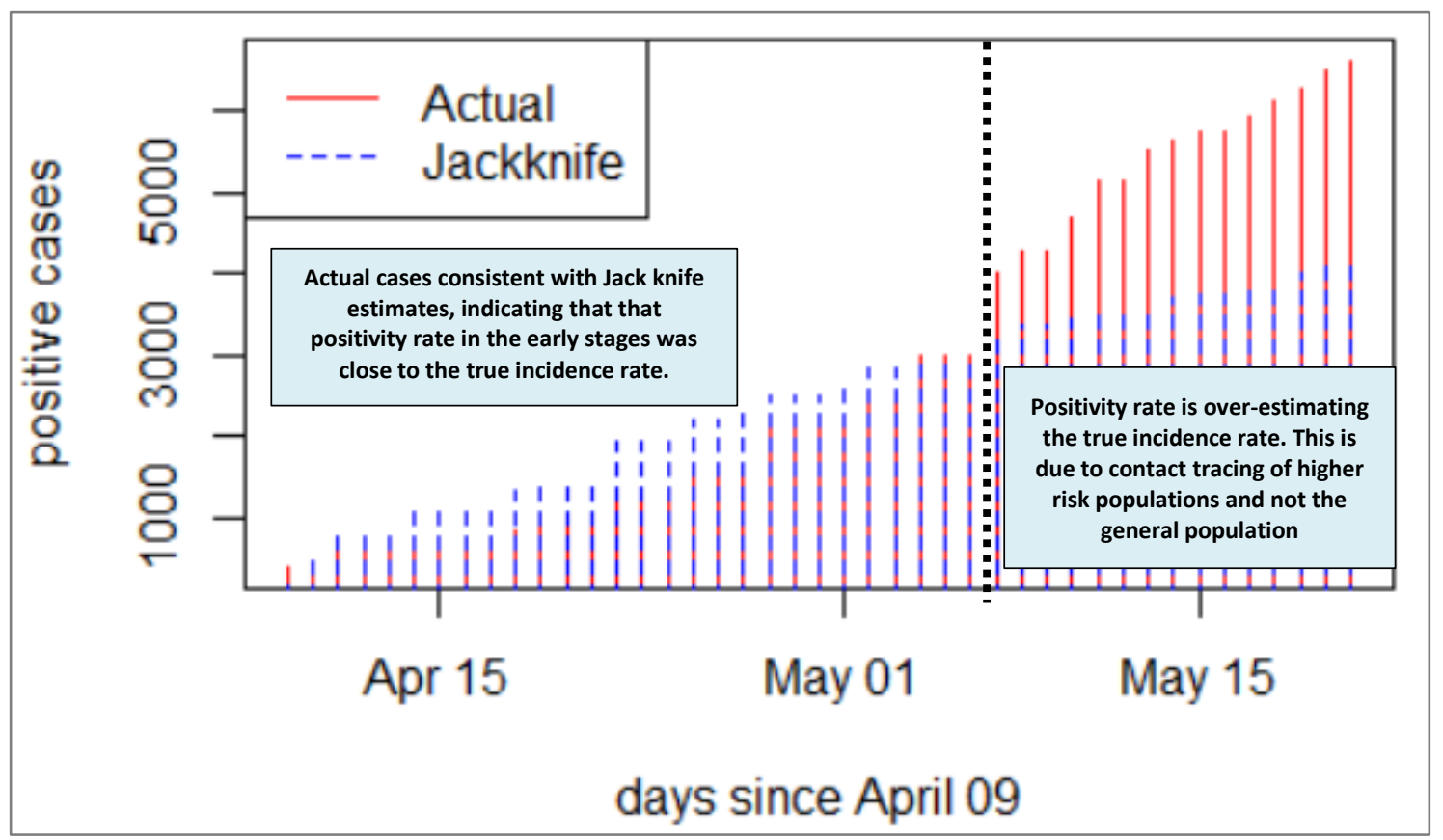

Source: Authors' estimates based on Ghana Health Service data

\subsection{Initial reproduction number $\left(R_{0}\right)$}

Several growth models for the initial outbreak of COVID-19 in Ghana were considered and presented in Table 1.

Table 1: Estimates of different parameter models

\begin{tabular}{|c|c|c|}
\hline Growth Model & Estimates (standard errors) & $\begin{array}{c}\text { Akaike Information Criterion } \\
\text { (AIC) }\end{array}$ \\
\hline Exponential & $0.095(0.002)^{* *}$ & -16914.29 \\
\hline Weibull & $2.15(0.062)^{* *}$ & -16946.64 \\
\hline Logistic & $0.17(0.006)^{* *}$ & -16991.13 \\
\hline Gompertz & $0.147(0.0051)^{* *}$ & -17011.42 \\
\hline
\end{tabular}

${ }^{* *}$ significant at $5 \%$ 
medRxiv preprint doi: https://doi.org/10.1101/2021.05.02.21256473; this version posted May 5, 2021. The copyright holder for this preprint (which was not certified by peer review) is the author/funder, who has granted medRxiv a license to display the preprint in perpetuity. It is made available under a CC-BY-NC-ND 4.0 International license.

The estimated models are shown below:

$$
\hat{\lambda}(t)= \begin{cases}4.9 e^{0.095 t} & \text { Exponential linear model } \\ 0.06 t^{2.15} & \text { Weibull model } \\ 190 \frac{0.008 e^{0.17 t}}{1+0.008 e^{0.17 t}} & \text { Logistic growth model } \\ 169.07\left(1-e^{-0.01 e^{0.147 t}}\right) & \text { Gompertz growth model }\end{cases}
$$

From Table 1, the underlying assumption behind the models is that in the initial stage of the epidemic, the number of infected individuals emerges at an exponential rate. We observe that the estimated growth rate for each model is statistically significant at $5 \%$ with the Gompertz model having the minimum AIC although all models were significantly close. The estimated growth rate from this model is 0.147 with 95\% C.I. [0.137-0.157]. From Equation (8), assuming a 15-day time to recovery after COVID-19 infection ${ }^{8}$, the initial reproduction number is estimated as 3.205. That is: $R_{O}=1+(0.147 * 15)=3.21$.

Table 2 shows our estimates of the initial reproduction number for Ghana compared with other countries. Ghana's initial reproduction number is very close to that reported for South Africa and Morocco, and also relatively close to Kenya, Algeria but further afield to figures from some Chinese provinces and South Korea. This result is also note-worthy for one key reason: during the early days of the pandemic, Ghana was testing relatively larger numbers than several African countries at a good rate by adopting a pooled sampling testing approach, which allowed a lot more COVID-19 tests to be conducted (WHO, 2020b; Nyazika et al., 2020). Ghana, for example, is reported as having conducted over 370,000 tests between March and mid-July 2020, putting the country among the highest in Africa with regard to number of tests when standardised by the population size (WHO, 2020b). Generally speaking, countries testing at a good rate were getting $R_{0}$ greater in the high $2 \mathrm{~s}$ and low $3 \mathrm{~s}$.

\footnotetext{
${ }^{8}$ CDC (2020). Interim Guidance on Duration of Isolation and Precautions for Adults with COVID-19Available at: https://www.cdc.gov/coronavirus/2019-ncov/hcp/duration-isolation.html (Accessed: 10 February 2021).
} 
medRxiv preprint doi: https://doi.org/10.1101/2021.05.02.21256473; this version posted May 5, 2021. The copyright holder for this preprint (which was not certified by peer review) is the author/funder, who has granted medRxiv a license to display the preprint in perpetuity.

Table 2: Estimates of R0 and comparison to other country studies

\begin{tabular}{|c|c|c|}
\hline Country & $\begin{array}{l}\text { Initial Reproduction Number } \\
\text { (R0) Estimate }\end{array}$ & Source \\
\hline Ghana & 3.21 & Authors' estimate \\
\hline South Africa & 3.20 & Zhao et al. (2020) \\
\hline Egypt & $\begin{array}{l}2.30 \\
2.29 \\
\end{array}$ & $\begin{array}{l}\text { Desouky (2020) } \\
\text { Zhao et al. (2020) } \\
\end{array}$ \\
\hline Algeria & 2.66 & Zhao et al. (2020) \\
\hline Morocco & 2.99 & Hammoumi \& Qesmi (2020) \\
\hline Kenya & 2.82 & Zhao et al. (2020) \\
\hline Nigeria & 2.29 & Zhao et al. (2020) \\
\hline China & $\begin{array}{l}4.03 \text { (Hubei Province) } \\
3.80 \text { (Wuhan) } \\
2.60 \text { (Wuhan) } \\
2.68 \text { (Wuhan) } \\
2.20 \text { (Wuhan) } \\
2.61 \text { (China) }\end{array}$ & $\begin{array}{l}\text { Choi \& Ki (2020) } \\
\text { Read et al. (2020) } \\
\text { Anastassopoulou et al. (2020) } \\
\text { Wu et al. (2020) } \\
\text { Li et al. (2020) } \\
\text { Wang et al. (2020) }\end{array}$ \\
\hline South Korea & 3.47-3.54 (Daegu/NGP) & Choi \& Ki (2020) \\
\hline United Kingdom & 2.6 & Jarvis et al. (2020) \\
\hline
\end{tabular}

\subsection{Time dependent and Sequential Bayesian reproduction number}

It will be necessary for the generation time distribution to be discretised using the same time unit. We therefore assumed a Gamma distribution for the generation time distribution with mean 3.57 and standard deviation 2.55 (Davies et al, 2020a; Davies et al., 2020b) when there are control measures in place. We also assumed that the infectious period is the same for asymptomatic and symptomatic cases. These methods require a time period over which there is an exponential growth.

The time period chosen is the date from first case(s) (March 12, 2020; day 1) to the date of maximum incidence (April 25, 2020; day 44) (Figure 3). From the two outputs in Figure 3 , the Sequential Bayesian does not make biological reasoning because the assumption of equal probabilities of $R_{0}$ does not hold (Clancy \& O'Neill, 2008). Hence, we opt for the time-dependent method. 
medRxiv preprint doi: https://doi.org/10.1101/2021.05.02.21256473; this version posted May 5, 2021. The copyright holder for this preprint (which was not certified by peer review) is the author/funder, who has granted medRxiv a license to display the preprint in perpetuity.

Figure 3: (a)Time dependent and (b) Sequential Bayesian reproduction number
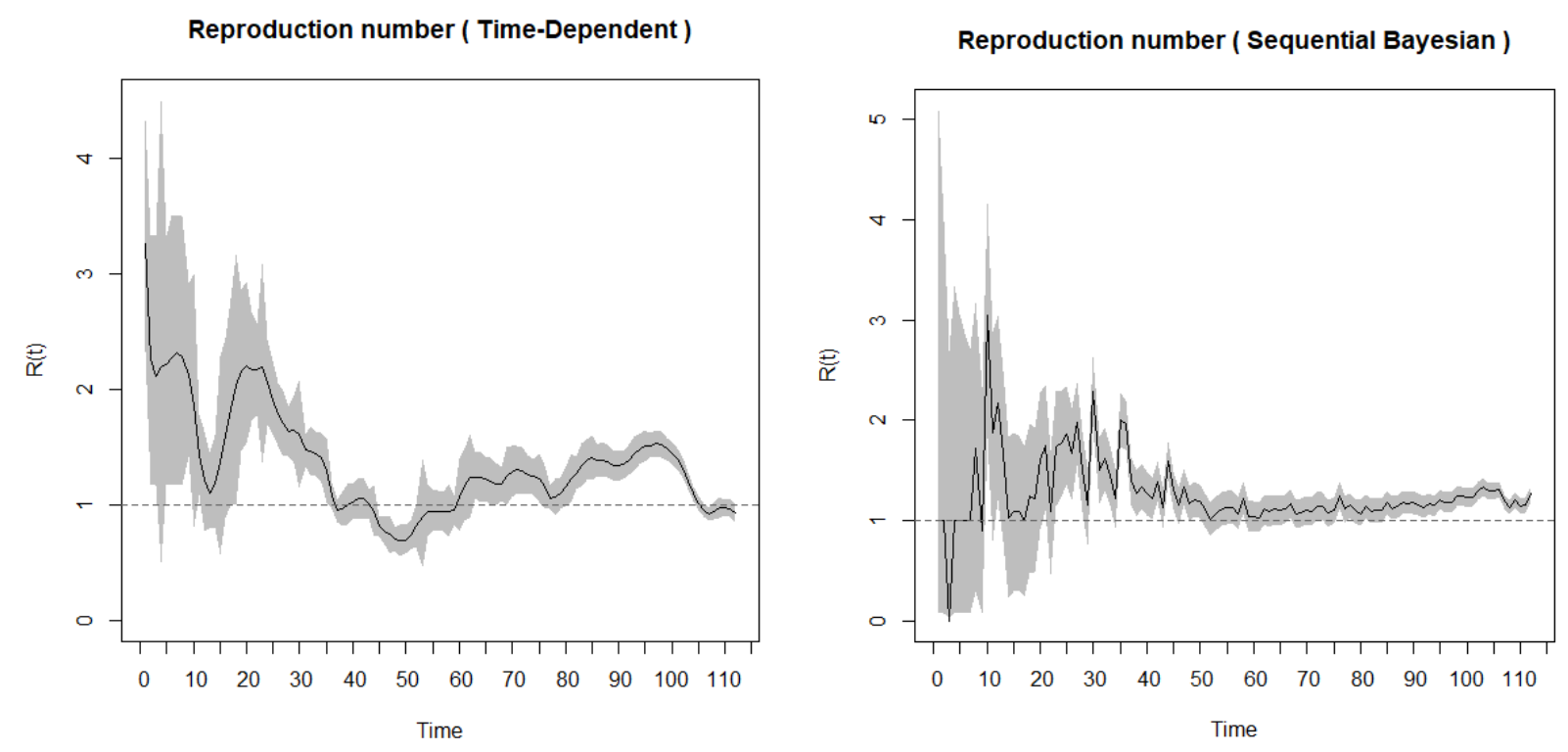

Source: Authors estimates, based on Ghana Health Service data

From Figure 4, the first estimates of $R_{0}$ in Ghana reflect the high rate of spread at the onset (March 12, 2020) of the pandemic outbreak. This was right before the mandatory quarantine of all persons entering the country, including events such as the ban on public gatherings, closure of schools, churches, mosques, and restriction of entry into Ghana for anyone who had been in a country with more than 200 COVID-19 cases. The spread of the disease measured by the $R_{0}$ then begins to decline after those key events from the first reported date (March 12, 2020) to the date of border closure (10 days interval). Between the date of border closure and right before the announcement of the partial lockdown of two regions (greater Accra, greater Kumasi), which reported more than 90\% of the cases, the spread of the disease increased moderately. After the initial lockdown, the spread of the disease reduced initially but begun to pick up momentum again from mid-April onwards with the easing of restrictions. This was despite the introduction of the wearing of mandatory facemasks, which were not fully complied with by citizens due the largely informal nature of settlements in the country making enforcement even more challenging.

In essence, the reproduction number reduces from March until mid-April during the lockdown, and then upsurged again when the country relaxed the initial restrictions. However, we note that the $R_{0}$ decreases further even after restrictions are eased (including when bars and hospitality venues were allowed to operate). With this observation, it can be inferred that the reproduction number and incidence rate paint an accurate picture of the COVID-19 spread in Ghana at the early stages of the pandemic from March to early May 2020. In these early stages, Ghana's actual cases of COVID-19 are consistent with the Jack-knife estimates (see Figure 2), indicating that that the positivity rate in the early stages was close to the true incidence rate. Beyond the early stages of the pandemic, it becomes difficult to make any deductive inferences based on the data available which might reflect the true situation. Our argument is further supported by that fact that contrasting to the $R_{0}$, the positivity rate, which ideally should be a proxy for the incidence rate, had been on the ascendency since mid-April (Figure 5). 
medRxiv preprint doi: https://doi.org/10.1101/2021.05.02.21256473; this version posted May 5, 2021. The copyright holder for this preprint (which was not certified by peer review) is the author/funder, who has granted medRxiv a license to display the preprint in perpetuity.

It is made available under a CC-BY-NC-ND 4.0 International license .

In essence, the reproduction number estimated will be unreliable if a country does not have a consistent and population representative testing regime. In Ghana's case, the reproduction number exhibits significant volatility as can be seen in the time-dependent charts (Figures 4 and 5), indicating that it is not representative of the true progression of the epidemic, as there was not a consistent testing regime in place. The reproduction number is a function of the frequency of potential exposures, and not having a consistent testing regime in place means that any such estimate is subject to misrepresentation and will be ineffective for use in evidence-based policy making. In fact, a very high positivity rate might actually be an indication that a country is not doing enough COVID-19 testing within the general population aimed at finding and isolating as many cases as possible in order to curb transmission.

\section{Figure 4: Time dependent $R_{0}$ superimposed on daily COVID-19 infections in Ghana}

Reproduction number, confirmed daily cases and public health measures as a function of time

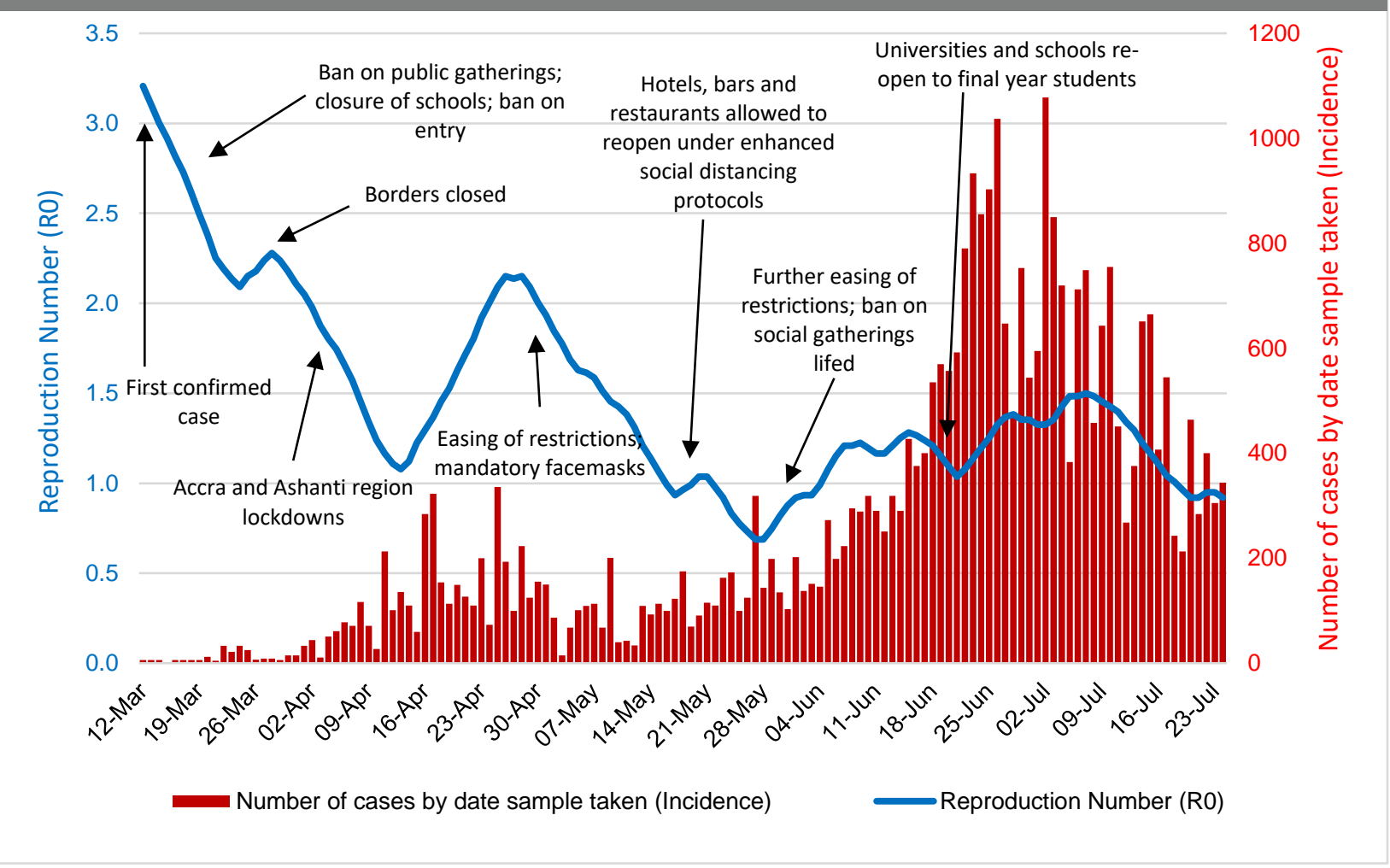

Source: Authors estimates, based on Ghana Health Service data 
medRxiv preprint doi: https://doi.org/10.1101/2021.05.02.21256473; this version posted May 5, 2021. The copyright holder for this preprint (which was not certified by peer review) is the author/funder, who has granted medRxiv a license to display the preprint in perpetuity.

Figure 5: Time dependent $\mathrm{R}_{0}$ superimposed on daily positivity rate in Ghana

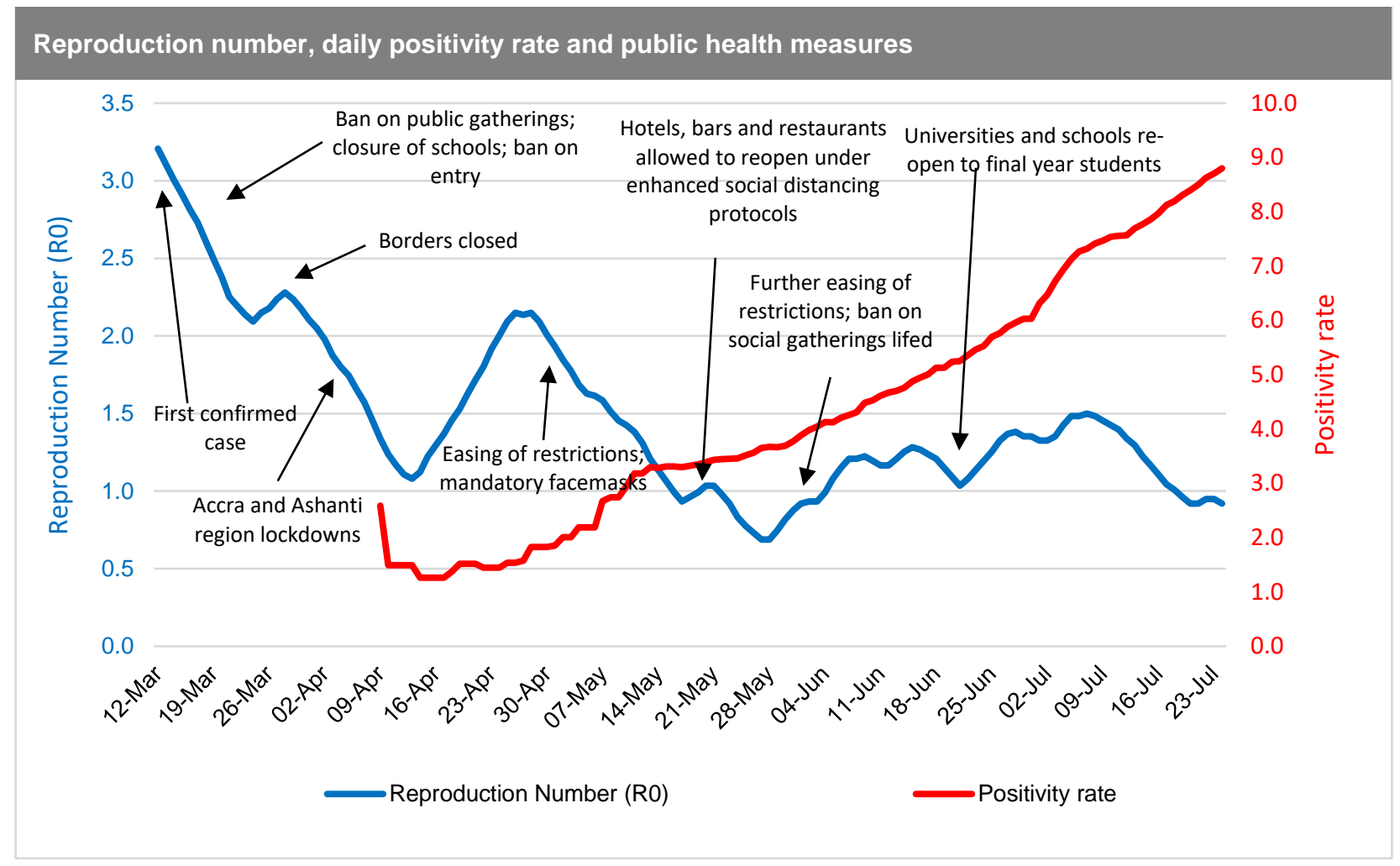

Source: Authors estimates, based on Ghana Health Service data

\subsection{Impact of easing restrictions on COVID-19 infection rates}

Next, we look at the intervention periods (Figure 6) and their mitigation effect on the rate of infections. As discussed in Section 2.2.3, we fitted a Negative-Binomial model with the log link function, by taking into account serial dependence which includes a regression on the two successive previous observations, and also include the six intervention effects detected by the model (Fokianos, 2015). Using this approach, we are able to assess the effect of interventions such as easing restrictions, on COVID-19 infection rates and to separate these from general trends and serial dependencies in time (Gilmour et al.,2006).

As can be seen in Table 3, there is a mixed a story of the impact of the mitigation effects of easing restrictions on COVID-19 infection rates. The initial three weeks following the confirmation of the first case on March 12 was characterised by a $25 \%$ increase in the rate of infection although this not statistically significant (Intervention Period 1). During this time, the Ghana government swiftly moved to impose a ban on all public gatherings, closure of schools, churches, mosques, among others. It also banned entry for anyone who has been to any country with more than 200 COVID-19 cases within 14 days. Intervention Period 2 was accompanied by the policy announcement of the mandatory quarantine for all those entering the country and the closure of air and land borders. The period was characterised by a $6 \%$ decrease in the rate of infection, but this was again not statistically significant impact.

Following this, Intervention Period 3 saw the government move to further impose the lockdown of Ghana's main population centres: the two geographic locations - Greater Accra region (5.06 million) and the city of Kumasi and its environs (3.4 million residents) which collectively account for about $27 \%$ of the country's 31 million population as of 2020. At the time of Intervention Period 3, we also see a $56 \%$ decrease in the rate of infection. However, this not statistically a significant impact. The Ghana government 
medRxiv preprint doi: https://doi.org/10.1101/2021.05.02.21256473; this version posted May 5, 2021. The copyright holder for this preprint (which was not certified by peer review) is the author/funder, who has granted medRxiv a license to display the preprint in perpetuity.

It is made available under a CC-BY-NC-ND 4.0 International license .

begun easing restrictions on these earlier lockdown measures imposed by Intervention Period 4. However, we observe a statistically significant $32 \%$ decline in rate of infection relative to previous intervention period. We explain this trend as possibly due to the residual positive effect of the preceding intervention period now kicking in, or due to a lag in the actual resumption of mass gatherings, as all had been cancelled and were either yet to be rescheduled or simply did not come off any longer. These are also confirmed in several studies, notably Meiksin (2020), Li et al. (2021) and Shengjie et al. (2020). For example, Meiksin (2020) notes in the context of the United Kingdom that the weekly death rate of registered COVID-19 deaths peaked just over three weeks after the partial lockdown and continued to decline. Li et al (2021) also found reduced COVID-19 transmission following the introduction of non-pharmaceutical interventions such as school closure, workplace closure and public events ban of between $3 \%$ to $24 \%$ on day 28 (four weeks) following the introduction, compared with the last day before introduction. Likewise, Shengjie et al. (2020) found that non-pharmaceutical interventions which were deployed in China were effective in containing the COVID-19 outbreak although the efficacy of the different interventions was dependent on early case detection and effective contact reduction.

Intervention Periods 5 and 6 were also occasioned by increases in the rate of infection as many citizens begun to fully get back to their normal activities and despite the use of facemasks now made mandatory. For example, hotels, bars and restaurants being allowed to reopen under enhanced social distancing protocols as part of further easing of restrictions. Additionally, the ban on social gatherings was lifted and universities and schools were re-open to final year students.

\section{Figure 6: Summary of intervention periods and public health measures imposed}

\begin{tabular}{|c|}
\hline $\begin{array}{l}\text { - First report of a case of COVID-19 by Ghana Health Service } \\
\text { - Ban on all public gatherings, closure of schools, churches, mosques, among others } \\
\text { - Ban on entry for anyone who has been to any country with more than } 200 \text { COVID- } \\
19 \text { cases within } 14 \text { days }\end{array}$ \\
\hline $\begin{array}{l}\text { Intervention Period 2: March 17-22, } 2020 \\
\text { - Mandatory quarantine for all those entering the country } \\
\text { - Borders closed }\end{array}$ \\
\hline $\begin{array}{l}\text { Intervention Period 3: March 23-30, } 2020 \\
\text { - Lockdown of two geographic locations (Greater Accra region and the city of Kumasi } \\
\text { and its environs) }\end{array}$ \\
\hline $\begin{array}{l}\text { Intervention Period 4: March } 31 \text { - April 20, } 2020 \\
\text { • Government of Ghana easing restrictions on lockdown measures }\end{array}$ \\
\hline $\begin{array}{l}\text { Intervention Period 5: April 21-26, } 2020 \\
\text {-Use of facemasks mandatory }\end{array}$ \\
\hline $\begin{array}{l}\text { Intervention Period 6: > April } 26,2020 \\
\text { • Hotels, bars and restaurants allowed to reopen under enhanced social distancing } \\
\text { protocols } \\
\text { - Further easing of restrictions; ban on social gatherings lifted } \\
\text { - Universities and schools re-open to final year students }\end{array}$ \\
\hline
\end{tabular}


medRxiv preprint doi: https://doi.org/10.1101/2021.05.02.21256473; this version posted May 5, 2021. The copyright holder for this preprint (which was not certified by peer review) is the author/funder, who has granted medRxiv a license to display the preprint in perpetuity.

Table 3: Testing for intervention effects. The null hypothesis $\left(H_{0}\right)$ is no intervention effect

\begin{tabular}{|c|c|c|c|c|c|}
\hline Date & $\begin{array}{l}\text { Interventi } \\
\text { on Type }\end{array}$ & Time(days) & $\begin{array}{l}\text { Coeff. } \\
\text { Estimates }\end{array}$ & $\begin{array}{l}\text { Multiplicative } \\
\text { effect (rate of } \\
\text { infection) }\end{array}$ & $\begin{array}{l}\text { Comment } \\
\text { Below 1= } \\
\text { decrease } \\
\text { Above 1= } \\
\text { increase }\end{array}$ \\
\hline $\begin{array}{l}\text { March } \\
12-17\end{array}$ & $\begin{array}{l}\text { Interventi } \\
\text { on Period } \\
1\end{array}$ & $\begin{array}{l}5<\text { intervent } \\
\text { ion }<=10\end{array}$ & 0.223 & $\begin{array}{l}\operatorname{Exp}(0.223) \\
\quad=1.250\end{array}$ & $\begin{array}{l}25 \% \text { increase in } \\
\text { the rate of } \\
\text { infection. } \\
\text { However, this not } \\
\text { statistically } \\
\text { significant impact }\end{array}$ \\
\hline $\begin{array}{l}\text { March } \\
17-22\end{array}$ & $\begin{array}{l}\text { Interventi } \\
\text { on Period } \\
2\end{array}$ & $\begin{array}{l}10<\text { interve } \\
\text { ntion<=18 }\end{array}$ & -0.066 & $\begin{array}{c}\operatorname{Exp}(-0.066)= \\
0.936\end{array}$ & $\begin{array}{l}6 \% \text { decrease in } \\
\text { the rate of } \\
\text { infection. } \\
\text { However, this not } \\
\text { statistically } \\
\text { significant impact }\end{array}$ \\
\hline $\begin{array}{l}\text { March } \\
23-30\end{array}$ & $\begin{array}{l}\text { Interventi } \\
\text { on Period } \\
3\end{array}$ & $\begin{array}{l}18<\text { interve } \\
\text { ntion }<=38\end{array}$ & 0.445 & $\begin{array}{c}\operatorname{Exp}(0.445)= \\
1.560\end{array}$ & $\begin{array}{l}56 \% \text { increase in } \\
\text { the rate of } \\
\text { infection. } \\
\text { However, this not } \\
\text { statistically } \\
\text { significant impact }\end{array}$ \\
\hline $\begin{array}{l}\text { March } \\
31- \\
\text { April } 20\end{array}$ & $\begin{array}{l}\text { Interventi } \\
\text { on Period } \\
4\end{array}$ & $\begin{array}{l}38<\text { interve } \\
\text { ntion }<=44\end{array}$ & $-0.382^{* * *}$ & $\begin{array}{c}\operatorname{Exp}(-0.382)= \\
0.682\end{array}$ & $\begin{array}{l}\text { Statistically } \\
\text { significant } 32 \% \\
\text { decline in rate of } \\
\text { infection. }\end{array}$ \\
\hline $\begin{array}{l}\text { April 21- } \\
26\end{array}$ & $\begin{array}{l}\text { Interventi } \\
\text { on Period } \\
5\end{array}$ & $\begin{array}{l}\begin{array}{l}\text { 44<interve } \\
\text { ntion }<=79\end{array}\end{array}$ & 0.129 & $\begin{array}{c}\operatorname{Exp}(0.129)= \\
1.138\end{array}$ & $\begin{array}{l}14 \% \text { increase in } \\
\text { rate of infection. } \\
\text { However, this not } \\
\text { statistically } \\
\text { significant impact }\end{array}$ \\
\hline$>26$ April & $\begin{array}{l}\text { Interventi } \\
\text { on Period } \\
6\end{array}$ & $\begin{array}{l}\text { Interventio } \\
n>79\end{array}$ & 0.043 & $\begin{array}{c}\operatorname{Exp}(-0.025)= \\
1.044\end{array}$ & $\begin{array}{l}4 \% \text { increase in } \\
\text { rate of infection. } \\
\text { However, this not } \\
\text { statistically } \\
\text { significant impact }\end{array}$ \\
\hline
\end{tabular}

Source: Authors' estimates $\left.\right|^{* * *}$ highly significant $(<0.001)$

\section{Conclusions}

The data available suggests that the COVID-19 lockdown and other restrictions in Ghana did actually reduce movement and interaction which would in turn had a positive effect in slowing down the spread of the virus in the early phase of the pandemic. This conclusion is further supported by anonymised and aggregated data from Mobile Network Operators on the mobility patterns of populations published by the Ghana Statistical Service for the period between February 17 and May 03, 2020 showing that person movements 
medRxiv preprint doi: https://doi.org/10.1101/2021.05.02.21256473; this version posted May 5, 2021. The copyright holder for this preprint (which was not certified by peer review) is the author/funder, who has granted medRxiv a license to display the preprint in perpetuity. It is made available under a CC-BY-NC-ND 4.0 International license .

decreased by up to $60 \%$ relative to the baseline value during the period when restrictions were in place.

The initial reproduction number $\left(R_{0}\right)$ is estimated from the statistical model as 3.21 using a 0.147 estimated growth rate and a 15-day time to recovery after COVID-19 infection. We observe that the estimated growth rate for each model is significant at $5 \%$, with the Gompertz model having the minimum AIC, although all models were significantly close. The estimate of the initial $R_{0}$ is consistent with what is reported in the literature from other parts of Africa, China and Europe. The $R_{0}$ reflects the high rate of spread at the outset of the pandemic in the country before the mandatory quarantine of all persons entering the country as well as the initial ban on public gatherings, among other public health interventions. The $R_{0}$ estimates and incidence rates could be seen as a fair reflection of the COVID-19 epidemiology at the early stages of the pandemic in Ghana (from March to early May 2020). From our analysis, Ghana's actual cases reported are consistent with the bootstrap Jack-knife estimates, indicating that that positivity rate in the early stages closely mirrored the incidence rate.

Going forward, there is a need more robust, consistent, systematic and representative sampling for testing, first to enable early detection, isolation and treatment of infected individuals and to reduce progression to severe disease and risk of mortality. Second, our recommended testing regime is critical for generating data for monitoring the impact of interventions to inform policy decisions, especially in this period of looming austerity.. We therefore recommend the widespread deployment of point-of-care diagnostics and later rapid diagnostic tests (RDT) - when they become more reliable, coupled with timely reporting and dissemination of results, as a first-line strategy towards mass surveillance of the population both to monitor the reproduction number and estimate the true incidence rate of COVID-19. The fore-mentioned measures are not only logistically less burdensome but would also prove timelier and more cost effective than running full-sample or pooled PCR tests.

Monitoring the impact of control measures on the evolution of the pandemic in Ghana will require being able to determine any changes in transmission rates, hospitalization rates and death rates over time. Each of these measures provide unique insights for disease control and prevention policy making and implementation but can only be determined by consistent, systematic and population representative testing mechanisms. Authorities would therefore need to rapidly set up a nationally representative monitoring systems involving sentinel sites, including schools, markets, places of worship, mass transit stations and other places of gathering in each of the 16 regions of Ghana. From these sentinel sites, a regular number of tests via an algorithm will need to be conducted (preferably on a daily basis), with results made available within $24-48 \mathrm{hrs}$. Results from this system could serve as the index for measuring the infectivity rate and subsequently, an accurate-enough time-dependent $R_{0}$ on a daily and weekly basis in different parts of the country.

While the results presented in this paper provide important insights into the early evolution of the pandemic in Ghana, we note that Ghana's daily incidence data at the early stages which has been used in the analysis, was sparse, lacked granularity and did not show a consistent trend. This means our assumptions of the disease parameter estimates must be applied cautiously to policy making, while improvements in sampling and testing strategies are improve as we have recommended. 
medRxiv preprint doi: https://doi.org/10.1101/2021.05.02.21256473; this version posted May 5, 2021. The copyright holder for this preprint (which was not certified by peer review) is the author/funder, who has granted medRxiv a license to display the preprint in perpetuity.

\section{Authorship statement}

All authors certify that they meet the criteria for authorship of the ICMJE

\section{Funding}

This research received no external funding.

\section{Declarations of Competing Interests}

Authors have no conflicts of interest to declare

\section{Data statement}

The data used in this study and $\mathrm{R}$ modelling code can be obtained on written request to the corresponding author.

\section{ORCID}

Nana Kena Frempong https://orcid.org/0000-0002-7138-3526

Theophilus Acheampong https://orcid.org/0000-0002-8026-9071

Ofosuhene O. Apenteng https://orcid.org/0000-0001-9991-1709

Emmanuel Nakua https://orcid.org/0000-0003-2949-1475

John H. Amuasi https://orcid.org/0000-0002-8640-2662

\section{References}

1. Africa CDC (2021). COVID-19 Daily Updates Available at: https://africacdc.org/covid-19 (Accessed: 9 April 2021).

2. Anastassopoulou, C., Russo, L., Tsakris, A., \& Siettos, C. (2020). Data-based analysis, modelling and forecasting of the COVID-19 outbreak. PloS one, 15(3), e0230405.

3. Brauer F. and C. Castillo-Chavez (2012). Mathematical models in population biology and epidemiology. No. 40 in Texts in applied mathematics, New York: Springer, 2nd ed. 2012.

4. CDC (2020). Interim Guidance on Duration of Isolation and Precautions for Adults with COVID-19. Available at: https://www.cdc.gov/coronavirus/2019ncov/hcp/duration-isolation.html (Accessed: 10 April 2021).

5. Choi, S. and Ki, M., 2020. Estimating the reproductive number and the outbreak size of COVID-19 in Korea. Epidemiology and health, 42.

6. Chowell, G., J. M. Hayman, L. M. A. Bettencourt, C. Castillo-Chavez (2014) Mathematical and Statistical Estimation Approaches in Epidemiology, Springer.

7. Chowell, G., Nishiura, H. and Bettencourt, L.M., 2007. Comparative estimation of the reproduction number for pandemic influenza from daily case notification data. Journal of the Royal Society Interface, 4(12), pp.155-166.

8. Clancy, D., \& O'Neill, P. D. (2008). Bayesian estimation of the basic reproduction number in stochastic epidemic models. Bayesian Analysis, 3(4), 737-757.

9. Cowling, B.J., Ali, S.T., Ng, T.W., Tsang, T.K., Li, J.C., Fong, M.W., Liao, Q., Kwan, M.Y., Lee, S.L., Chiu, S.S. and Wu, J.T., 2020. Impact assessment of non-pharmaceutical 
medRxiv preprint doi: https://doi.org/10.1101/2021.05.02.21256473; this version posted May 5, 2021. The copyright holder for this preprint (which was not certified by peer review) is the author/funder, who has granted medRxiv a license to display the preprint in perpetuity. It is made available under a CC-BY-NC-ND 4.0 International license .

interventions against coronavirus disease 2019 and influenza in Hong Kong: an observational study. The Lancet Public Health, 5(5), pp.e279-e288.

10. Cucinotta, D., \& Vanelli, M. (2020). WHO Declares COVID-19 a Pandemic. Acta biomedica: Atenei Parmensis, 91(1), 157-160. https://doi.org/10.23750/abm.v91i1.9397

11. Dalton, C., Corbett, S., \& Katelaris, A. (2020). Pre-emptive low cost social distancing and enhanced hygiene implemented before local COVID-19 transmission could decrease the number and severity of cases. The Medical Journal of Australia, 212(10), 1.

12. Danon, L., Brooks-Pollock, E., Bailey, M., \& Keeling, M. J. (2020). A spatial model of CoVID-19 transmission in England and Wales: early spread and peak timing. medRxiv.

13. Danquah, M. \& Schotte, S. (2020). COVID-19 and the socioeconomic impact in Africa: The case of Ghana. WIDER Background Note 2020/5. Helsinki: UNU-WIDER.

14. Davies, N.G., Klepac, P., Liu, Y., Prem, K., Jit, M., Eggo, R.M. and CMMID COVID-19 working group (2020a). Age-dependent effects in the transmission and control of COVID-19 epidemics. MedRxiv.

15. Davies, N.G., Kucharski, A.J., Eggo, R.M., Gimma, A., Edmunds, W.J. and CMMID COVID-19 Working Group (2020b). The effect of non-pharmaceutical interventions on COVID-19 cases, deaths and demand for hospital services in the UK: a modelling study. MedRxiv.

16. Delamater, P. L., Street, E. J., Leslie, T. F., Yang, Y. T., \& Jacobsen, K. H. (2019). Complexity of the basic reproduction number (R0). Emerging infectious diseases, 25(1), 1.

17. Dharmaratne, S., Sudaraka, S., Abeyagunawardena, I., Manchanayake, K., Kothalawala, M. and Gunathunga, W., 2020. Estimation of the basic reproduction number (RO) for the novel coronavirus disease in Sri Lanka. Virology Journal, 17(1), pp.1-7.

18. Diekmann, O. and Heesterbeek, J.A.P., 2000. Mathematical epidemiology of infectious diseases: model building, analysis and interpretation (Vol. 5). John Wiley \& Sons.

19.Diekmann, O., Heesterbeek, J.A.P. and Metz, J.A., 1990. On the definition and the computation of the basic reproduction ratio RO in models for infectious diseases in heterogeneous populations. Journal of mathematical biology, 28(4), pp.365-382.

20.Diop, B.Z., Ngom, M., Biyong, C.P. and Biyong, J.N.P., 2020. The relatively young and rural population may limit the spread and severity of COVID-19 in Africa: a modelling study. BMJ global health, 5(5), p.e002699.

21. Eikenberry, S. E., Mancuso, M., Iboi, E., Phan, T., Eikenberry, K., Kuang, Y., \& Gumel, A. B. (2020). To mask or not to mask: Modeling the potential for face mask use by the general public to curtail the COVID-19 pandemic. Infectious Disease Modelling.

22. El Desouky, E.D., 2020. Prediction of the Epidemic Peak of Covid19 in Egypt, 2020. medRxiv.

23. Fang, L., Karakiulakis, G. and Roth, M., 2020. Are patients with hypertension and diabetes mellitus at increased risk for COVID-19 infection?. The Lancet. Respiratory Medicine.

24. Farrington $C$ (2008) Modelling epidemics. The Open University, Milton Keynes.

25. Farrington, C. P., Kanaan, M. N., \& Gay, N. J. (2001). Estimation of the basic reproduction number for infectious diseases from age-stratified serological survey data. Journal of the Royal Statistical Society: Series C (Applied Statistics), 50(3), 251292.

26. Feng, Z., 2007. Final and peak epidemic sizes for SEIR models with quarantine and isolation. Mathematical Biosciences \& Engineering, 4(4), p.675.

27. Fokianos K (2015). "Statistical Analysis of Count Time Series Models: A GLM Perspective." In R Davis, S Holan, R Lund, N Ravishanker (eds.), Handbook of 
medRxiv preprint doi: https://doi.org/10.1101/2021.05.02.21256473; this version posted May 5, 2021. The copyright holder for this preprint (which was not certified by peer review) is the author/funder, who has granted medRxiv a license to display the preprint in perpetuity. It is made available under a CC-BY-NC-ND 4.0 International license .

Discrete-Valued Time Series, Handbooks of Modern Statistical Methods, pp. 3-28.

Chapman \& Hall, London.

28. Fokianos K, \& Fried R (2010). "Interventions in INGARCH Processes." Journal of Time Series Analysis, 31(3), 210-225. doi:10.1111/j.1467-9892.2010.00657.x.

29. Fokianos K, \& Fried R (2012). "Interventions in Log-Linear Poisson Autoregression." Statistical Modelling, 12(4), 299-322. doi:10.1177/1471082X1201200401.

30. Ghana Health Service (2020). COVID-19 Updates. Available at: https://www.ghanahealthservice.org/covid19/archive.php (Accessed: 15 February 2021).

31. Ghana Statistical Service (2020). Mobility analysis to support the Government of Ghana in responding to the COVID-19 outbreak. Available at: https://statsghana.gov.gh/COVID-19\%20press\%20release\%20report\%20\%20analysis\%20overview\%20-\%20final.pdf (Accessed: 15 February 2021).

32. Gilbert, M., Pullano, G., Pinotti, F., Valdano, E., Poletto, C., Boëlle, P.Y., d'Ortenzio, E., Yazdanpanah, Y., Eholie, S.P., Altmann, M. and Gutierrez, B., 2020. Preparedness and vulnerability of African countries against importations of COVID-19: a modelling study. The Lancet, 395(10227), pp.871-877.

33. Gilmour, S., Degenhardt, L., Hall, W. and Day, C., 2006. Using intervention time series analyses to assess the effects of imperfectly identifiable natural events: a general method and example. BMC medical research methodology, 6(1), pp.1-9.

34. Guan, W.J., Liang, W.H., Zhao, Y., Liang, H.R., Chen, Z.S., Li, Y.M., Liu, X.Q., Chen, R.C., Tang, C.L., Wang, T. and Ou, C.Q., 2020. Comorbidity and its impact on 1590 patients with Covid-19 in China: A Nationwide Analysis. European Respiratory Journal, 55(5).

35. Hammoumi, A. and Qesmi, R., 2020. Impact assessment of containment measure against COVID-19 spread in Morocco. Chaos, Solitons \& Fractals, 140, p.110231.

36. Hellewell, J., Abbott, S., Gimma, A., Bosse, N. I., Jarvis, C. I., Russell, T. W., ... \& Flasche, S. (2020). Feasibility of controlling COVID-19 outbreaks by isolation of cases and contacts. The Lancet Global Health.

37. Hong, H. G., \& Li, Y. (2020). Estimation of time-varying reproduction numbers underlying epidemiological processes: A new statistical tool for the COVID-19 pandemic. PloS one, 15(7), e0236464.

38. Jarvis, C.I., Van Zandvoort, K., Gimma, A., Prem, K., Klepac, P., Rubin, G.J. and Edmunds, W.J., 2020. Quantifying the impact of physical distance measures on the transmission of COVID-19 in the UK. BMC medicine, 18, pp.1-10.

39. Johns Hopkins University (2021). COVID-19 Map - Johns Hopkins Coronavirus Resource Center. Available at: https://coronavirus.jhu.edu/map.html (Accessed: 15 February 2021).

40. K. Dietz, "The estimation of the basic reproduction number for infectious diseases," Statistical Methods in Medical Research, vol. 2, no. 1, pp. 23-41, 1993.

41. Kamali Aghdam, M., Jafari, N., \& Eftekhari, K. (2020). Novel coronavirus in a 15-dayold neonate with clinical signs of sepsis, a case report. Infectious Diseases, 52(6), 427-429.

42. Kermack, W. O., and A. G. McKendrick. 1927. "A Contribution to the Mathematical Theory of Epidemics." Proceedings of the Royal Society of London, Series A, Vol. 115, No. 772: 700-721.

43. Kramer A, Kretzchmar M, Krickeberg K (eds) (2010) Modern infectious disease epidemiology: concepts, methods, mathematical models, and public health. Springer, Berlin

44. Leung, K., Wu, J.T., Liu, D. and Leung, G.M., 2020. First-wave COVID-19 transmissibility and severity in China outside Hubei after control measures, and 
medRxiv preprint doi: https://doi.org/10.1101/2021.05.02.21256473; this version posted May 5, 2021. The copyright holder for this preprint (which was not certified by peer review) is the author/funder, who has granted medRxiv a license to display the preprint in perpetuity.

It is made available under a CC-BY-NC-ND 4.0 International license .

second-wave scenario planning: a modelling impact assessment. The Lancet, 395(10233), pp.1382-1393.

45. Li, Q., Guan, X., Wu, P., Wang, X., Zhou, L., Tong, Y., Ren, R., Leung, K.S., Lau, E.H., Wong, J.Y. and Xing, X., 2020. Early transmission dynamics in Wuhan, China, of novel coronavirus-infected pneumonia. New England journal of medicine.

46. Li, Y., Campbell, H., Kulkarni, D., Harpur, A., Nundy, M., Wang, X., Nair, H. and for COVID, U.N., 2021. The temporal association of introducing and lifting nonpharmaceutical interventions with the time-varying reproduction number $(R)$ of SARS-CoV-2: a modelling study across 131 countries. The Lancet Infectious Diseases, 21(2), pp.193-202.

47. Li, Y., Campbell, H., Kulkarni, D., Harpur, A., Nundy, M., Wang, X., ... \& for COVID, U. N. (2021). The temporal association of introducing and lifting non-pharmaceutical interventions with the time-varying reproduction number (R) of SARS-CoV-2: a modelling study across 131 countries. The Lancet Infectious Diseases, 21(2), 193-202.

48. Ma, J., 2020. Estimating epidemic exponential growth rate and basic reproduction number. Infectious Disease Modelling, 5, pp.129-141.

49. Ma, J., Dushoff, J., Bolker, B.M. and Earn, D.J., 2014. Estimating initial epidemic growth rates. Bulletin of mathematical biology, 76(1), pp.245-260.

50. Maxmen, A., 2021. Why did the world's pandemic warning system fail when COVID hit?. Nature, 589(7843), pp.499-500.

51. McCullagh P, Nelder J (1989) Generalized linear models. Chapman \& Hall, London

52. Meiksin, A., 2020. Dynamics of COVID-19 transmission including indirect transmission mechanisms: a mathematical analysis. Epidemiology \& Infection, 148.

53. Moore, S. E., \& Okyere, E. (2020). Controlling the transmission dynamics of COVID19. arXiv preprint arXiv:2004.00443.

54. Muniyappa, R. and Gubbi, S., 2020. COVID-19 pandemic, coronaviruses, and diabetes mellitus. American Journal of Physiology-Endocrinology and Metabolism, 318(5), pp.E736-E741.

55. Ng, T. C., \& Wen, T. H. (2019). Spatially adjusted time-varying reproductive numbers: understanding the geographical expansion of urban dengue outbreaks. Scientific reports, 9(1), 1-12.

56. Nyazika, T.K., Kaela, R., Mugoni, M., Musomekwa, K., Kyei-Baafour, E., Chiwanda, S., Mapondera, P.T., Makawa, T.S., Sithole, E.M., Mavunganidze, G. and Manasa, J., 2020. Implementation of antibody rapid diagnostic testing versus real-time reverse transcription-PCR sample pooling in the screening of COVID-19: a case of different testing strategies in Africa. MSphere, 5(4).

57. Obadia, T., Haneef, R. and Boëlle, P.Y., 2012. The RO package: a toolbox to estimate reproduction numbers for epidemic outbreaks. BMC medical informatics and decision making, 12(1), p.147.

58. OurWorldInData (2021). Coronavirus Pandemic Data Explorer. Available at: https://ourworldindata.org/coronavirus-dataexplorer?zoomToSelection=true\&time $=2020-03-$ 01..latest\&country $=\mathrm{GHA} \sim Z A F \sim K E N \sim N G A \sim S E N \&$ region=World\&testsMetric=true\&i nterval=smoothed\&perCapita=true\&smoothing=7\&pickerMetric=total cases\&picker Sort=desc (Accessed: 15 February 2021).

59. Overgaard, M., Parner, E. T., \& Pedersen, J. (2017). Asymptotic theory of generalized estimating equations based on jack-knife pseudo-observations. Annals of Statistics, 45(5), 1988-2015.

60. Rao, J. N., \& Shao, J. (1992). Jackknife variance estimation with survey data under hot deck imputation. Biometrika, 79(4), 811-822 
medRxiv preprint doi: https://doi.org/10.1101/2021.05.02.21256473; this version posted May 5, 2021. The copyright holder for this preprint (which was not certified by peer review) is the author/funder, who has granted medRxiv a license to display the preprint in perpetuity. It is made available under a CC-BY-NC-ND 4.0 International license.

61. Read, J.M., Bridgen, J.R., Cummings, D.A., Ho, A. and Jewell, C.P., 2020. Novel coronavirus 2019-nCoV: early estimation of epidemiological parameters and epidemic predictions. MedRxiv.

62. Ridenhour, B., Kowalik, J.M. and Shay, D.K., 2018. Unraveling r 0: Considerations for public health applications. American journal of public health, 108(S6), pp.S445-S454.

63. Rypdal, M., Rypdal, V., Jakobsen, P.K., Ytterstad, E., Løvsletten, O., Klingenberg, C. and Rypdal, K., 2021. Modelling suggests limited change in the reproduction number from reopening Norwegian kindergartens and schools during the COVID-19 pandemic. PloS one, 16(2), p.e0238268.

64. Santamaría, L. and Hortal, J. (2021). COVID-19 effective reproduction number dropped during Spain's nationwide dropdown, then spiked at lower-incidence regions. Science of the Total Environment, 751, p.142257.

65. Shengjie, L., Ruktanonchai, N.W. and Zhou, L., 2020. Effect of non-pharmaceutical interventions for containing the COVID-19 outbreak in China. medRxiv preprint.

66. Sibiri, H., Prah, D. and Zankawah, S.M., 2020. Containing the impact of COVID-19: Review of Ghana's response approach. Health policy and technology.

67. Wang, K., Zhao, S., Li, H., Song, Y., Wang, L., Wang, M.H., Peng, Z., Li, H. and He, D., 2020. Real-time estimation of the reproduction number of the novel coronavirus disease (COVID-19) in China in 2020 based on incidence data. Annals of translational medicine, 8(11).

68. Wallinga, J. and Teunis, P. (2004). Different epidemic curves for severe acute respiratory syndrome reveal similar impacts of control measures. American Journal of epidemiology, 160(6), pp.509-516.

69. Wilson, N., Barnard, L. T., Kvalsig, A., Verrall, A., Baker, M. G., \& Schwehm, M. (2020). Modelling the Potential Health Impact of the COVID-19 Pandemic on a Hypothetical European Country. medRxiv.

70. Wilson, N., Barnard, L. T., Kvalsvig, A., \& Baker, M. (2020). Potential Health Impacts from the COVID-19 Pandemic for New Zealand if Eradication Fails: Report to the NZ Ministry of Health.

71. World Health Organization (2020a). Pandemic (Covid19)-Update. Available at: https://www.who.int/emergencies/diseases/novel-coronavirus-2019 (Accessed: 10 February 2021).

72. World Health Organization (2020b).Pooling samples boosts Ghana's COVID-19 testing. Available at: https://www.who.int/news-room/featurestories/detail/pooling-samples-boosts-ghana-s-covid-19-testing (Accessed: 10 April 2021).

73. World Health Organization (2019). Non-pharmaceutical public health measures for mitigating the risk and impact of epidemic and pandemic influenza: annex: report of systematic literature reviews. World Health Organization. Available at: https://apps.who.int/iris/handle/10665/329439. (Accessed: 10 December 2020).

74.Wu, J.T., Leung, K. and Leung, G.M., 2020. Nowcasting and forecasting the potential domestic and international spread of the 2019-nCoV outbreak originating in Wuhan, China: a modelling study. The Lancet, 395(10225), pp.689-697.

75.Zhang, J., Nonvignon, J., and Mao, W. (2020). How well is Ghana-with one of the best testing capacities in Africa-responding to COVID-19?, Brookings. Available at: https://www.brookings.edu/blog/future-development/2020/07/28/how-well-isghana-with-one-of-the-best-testing-capacities-in-africa-responding-to-covid-19 (Accessed: 15 February 2021).

76.Zhao, Z., Li, X., Liu, F., Zhu, G., Ma, C. and Wang, L., 2020. Prediction of the COVID19 spread in African countries and implications for prevention and control: A case 
medRxiv preprint doi: https://doi.org/10.1101/2021.05.02.21256473; this version posted May 5, 2021. The copyright holder for this preprint (which was not certified by peer review) is the author/funder, who has granted medRxiv a license to display the preprint in perpetuity.

It is made available under a CC-BY-NC-ND 4.0 International license .

study in South Africa, Egypt, Algeria, Nigeria, Senegal and Kenya. Science of the Total Environment, 729, p.138959. 